Article

\title{
Two New Coumarins from Micromelum falcatum with Cytotoxicity and Brine Shrimp Larvae Toxicity
}

\section{Xiongming Luo, Weihong He, Hao Yin, Qingxin Li, Qiao Liu, Yongzhong Huang and Si Zhang *}

Key Laboratory of Marine Bio-resourses Sustainable Utilization, South China Sea Institute of Oceanology, Chinese Academy of Sciences, Guangzhou 510301, China; E-Mails: luoxm163@sina.com (X.L.); whhe@scsio.ac.cn (W.H.); yinhao@scsio.ac.cn (H.Y.); liqx81@163.com (Q.L.); lq_11@hotmail.com (Q.L.); tj6188@sina.com (Y.H.)

* Author to whom correspondence should be addressed; E-Mail: zhsimd@scsio.ac.cn; Tel./Fax: +86-20-8902-3105.

Received: 30 March 2012; in revised form: 11 May 2012 / Accepted: 11 May 2012 / Published: 6 June 2012

\begin{abstract}
Two new coumarins, 7-methoxy-8-(2-hydroxmethyl-1-O-isovaleryl-4-butenyl)coumarin (1) and 7-methoxy-8-(1-hydroxy-2-O- $\beta$-glucopyranosyl-3-methyl-4-butene-1yl)coumarin (2), and twelve known coumarins 3-14 were isolated from the stem bark of Micromelum falcatum. The structures of compounds 1-14 were elucidated by extensive spectroscopic data analyses. The toxicity of compounds 1-14 was tested using a brine shrimp assay and in vitro antiproliferative assay against mammary cancer (F10) and lung cancer (HvEvc) cell lines by the MTT method. Some compounds had moderate activities. All compounds were also tested against the microorganisms Bacillus subtilis, Bacillus thuringiensis and Escherichia coli, but no activity was observed.
\end{abstract}

Keywords: Micromelum falcatum; coumarins; brine shrimp larvae toxicity; cytotoxicity; antibacterial activity

\section{Introduction}

The genus Micromelum (Rutaceae family) contains about 11 species which are distributed in Asian tropical and subtropical regions. Phytochemically, many bioactive compounds, including 6- and 8-shi aprenylated coumarins, polyoxygenated flavonoids, dimeric indole alkaloids and carbazole alkaloids 
were isolated from this genus [1-8]. M. falcatum (Lour.) Tan. is a medicinal plant mainly distributed in southern and southwestern China, and widely used in Chinese folk medicine to treat infected wounds, odynolysis, rheumatism, cough and fevers. Early studies of this species have resulted in the isolation of four alkaloids, ten coumarins and three dihydrocinnamic acid derivatives from its leaves and roots collected from Vietnam and China. Many 6- and 8-prenylated coumarins have been reported showing both in vitro and in vivo antitumor activity [5-11]. For instance, micromelin exhibited significant in vivo activity in mice against P-388 lymphocytic leukemia (T/C $149 \%$ at $10 \mathrm{mg} / \mathrm{Kg}$ ) and Lewis lung carcinoma (T/C $228 \%$ at $1.25 \mathrm{mg} / \mathrm{Kg}$ ) [9], and murrangatin and minumicrolin were valuable anti-tumor promoting agents [10] while microminutin (3) [11] displayed in vitro activity $\left(\mathrm{ED}_{50} 3.7 \mu \mathrm{g} / \mathrm{mL}\right)$ in the P-388 lymphocytic leukemia test system.

In order to search for new antitumor agents, we further investigated the chemical constituents of this species. Herein, we report the isolation and structure elucidation of two new coumarins, 7-methoxy-8(2-hydroxymethyl-1-O-isovaleryl-4-butenyl)coumarin (1) and 7-methoxy-8-(1-hydroxy-2-O- $\beta$-glucopyranosyl-3-methyl-4-butene-1-yl)coumarin (2), and twelve known coumarins, microminutin (3) [11], 6-formyl-7-methoxycoumarin (4) [12], murralongin (5) [13,14], murraol (6) [15], arscotin (7) [16], murralonginol (8) [17], (E)-osthenone (9) [18], isomurralonginol (10) [13,14], murracarpin (11) [16], microminutinin (12) [6,19], methoxymicrominutinin (13) [6,19] and microfalcatin isovalerate (14) [6] from the stem bark of $M$. falcatum. The brine shrimp toxicity and cytotoxicity data of compounds 1-14 are also disclosed. No activity was observed in antibacterial tests of all isolated compounds against the strains Bacillus subtilis, Bacillus thuringiensis and Escherichia coli.

\section{Results and Discussion}

The stem bark of $M$. falcatum was extracted with ethanol to yield a crude extract. The crude extract was dissolved in $\mathrm{H}_{2} \mathrm{O}$, extracted first with $n$-hexane and then with EtOAc. The EtOAc extract was separated by sequential chromatography on a normal phase silica gel flash column, Sephadex LH-20 column and reversed phase HPLC to afford two new compounds 1-2 and twelve known compounds 3-14. The known compounds was identified as microminutin (3), 6-formyl-7-methoxycoumarin (4), murralongin (5), murraol (6), arscotin (7), murralonginol (8), (E)-osthenone (9), isomurralonginol (10), murracarpin (11), microminutinin (12), methoxymicrominutinin (13) and microfalcatin isovalerate (14), on the basis of MS, ${ }^{1} \mathrm{H}$ - and ${ }^{13} \mathrm{C}-\mathrm{NMR}$ data analyses and comparisons with relevant literature reports.

Compound 1 was isolated as a colorless oil and had the molecular formula $\mathrm{C}_{20} \mathrm{H}_{24} \mathrm{O}_{6}$ as determined by HREI-MS $\left(\mathrm{m} / \mathrm{z}: 360.1574[\mathrm{M}]^{+}\right)$. The UV spectrum of $\mathbf{1}(283.0,323.3 \mathrm{~nm})$ exhibited the charicteristic absorption bands of a 7-oxygenated coumarin skeleton and the IR data (3540, 1739, 1733, 1605, 1543, 1450, $1224 \mathrm{~cm}^{-1}$ ) showed benzene ring, ester and hydroxy groups. Detailed analyses of the 1D and 2D (COSY, HSQC, and HMBC) NMR spectral data (Table 1) of 1 revealed the presence of an 8-substituted 7-methoxycoumarin moiety, an isovaleryl moiety, and a $\Delta^{1^{\prime}-4^{\prime}, 5^{\prime}-}$ dioxygenated isoprenyl moiety. The COSY correlations between H-4" $(\delta 0.96) / \mathrm{H}-3$ " $(\delta$ 2.12)/H-2" $(\delta$ 2.24) and HMBC correlations observed from H-2" to C-1" ( $\delta$ 173.5), C-3" ( $\delta$ 25.7), C-4" $(\delta 22.5)$ and C-5" ( $\delta$ 22.5), from H-3" to C-1", C-2" ( $\delta 43.4), C-4 "$ and C-5", and from H-4" to C-2", C-3", and $\mathrm{C}-5^{\prime \prime}$, proved the presence of the isovaleryl moiety. The COSY correlations between $\mathrm{H}-1^{\prime}(\delta 6.90) / \mathrm{H}-2^{\prime}$ $\left(\delta\right.$ 6.68), H-2'/H-3' $(\delta 2.82), \mathrm{H}-3^{\prime} / \mathrm{H}-4^{\prime}\left(\delta\right.$ 4.30), and $\mathrm{H}-3^{\prime} / \mathrm{H}-5^{\prime}(\delta$ 3.76), suggested the presence of 


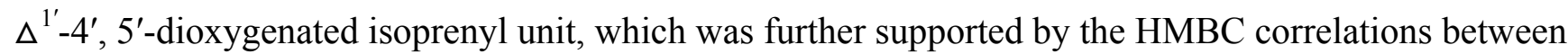
$\mathrm{H}-1^{\prime} / \mathrm{C}-2^{\prime} / \mathrm{C}-3^{\prime}, \mathrm{H}-2^{\prime} / \mathrm{C}-3^{\prime} / \mathrm{C}-4^{\prime}, \mathrm{H}-3^{\prime} / \mathrm{C}-2^{\prime} / \mathrm{C}-4^{\prime}, \mathrm{H}-4^{\prime} / \mathrm{C}-2^{\prime} / \mathrm{C}-3^{\prime} / \mathrm{C}-5^{\prime}$, and H-5'/C-2'/C-3'/C-4'. The three moieties were readily assembled through a $\mathrm{C}-1^{\prime \prime} / \mathrm{C}-4^{\prime}$ ester linkage and a $\mathrm{C}-1^{\prime} / \mathrm{C}-8$ carbon-carbon bond, on the basis of the HMBC correlations observed between $\mathrm{H}-4^{\prime} / \mathrm{C}-1^{\prime \prime}(\delta 173.5)$ and $\mathrm{H}-1^{\prime} / \mathrm{C}-7 / \mathrm{C}-8 / \mathrm{C}-9$, repectively. The 5'-hydroxy group was deduced from the $1 \mathrm{D}$ NMR and ESI-MS data. The HMBC correlation between $\delta_{\mathrm{H}} 3.93(3 \mathrm{H}, \mathrm{s})$ and $\mathrm{C}-7(\delta$ 160.2) located the methoxyl group at C-7. The $16.4 \mathrm{~Hz}$ coupling constant between $\mathrm{H}-1^{\prime}$ and $\mathrm{H}-2^{\prime}$, indicated that the double bond at C-1' and C-2' was trans. Hence, compound $\mathbf{1}$ was identified as 7-methoxy-8-(2-hydroxmethyl-1-O-isovaleryl-4-butenyl)coumarin (Figure 1).

Table 1. ${ }^{1} \mathrm{H}$ NMR $(500 \mathrm{~Hz})$ and ${ }^{13} \mathrm{C}-\mathrm{NMR}(125 \mathrm{MHz})$ Data for Compounds $\mathbf{1}$ and $\mathbf{2}^{\mathrm{a}}$.

\begin{tabular}{|c|c|c|c|c|c|c|}
\hline & & DMSO-d 6 ) & & & (eOD) & \\
\hline & ${ }^{1}$ H-NMR & ${ }^{13} \mathrm{C}-\mathrm{NMR}$ & HMBC & ${ }^{1}$ H-NMR & ${ }^{13} \mathrm{C}-\mathrm{NMR}$ & HМВC \\
\hline 2 & & 160.8 & & & 162.8 & \\
\hline 3 & $6.26(1 \mathrm{H}, \mathrm{d}, 9.5 \mathrm{~Hz})$ & 113.2 & $\mathrm{C}-2,4$ & $6.26(1 \mathrm{H}, \mathrm{d}, 9.5 \mathrm{~Hz})$ & 113.3 & $\mathrm{C}-2,4,10$ \\
\hline 4 & $7.62(1 \mathrm{H}, \mathrm{d}, 9.5 \mathrm{~Hz})$ & 143.8 & $\mathrm{C}-2,3,5,10$ & $7.89(1 \mathrm{H}, \mathrm{d}, 9.5 \mathrm{~Hz})$ & 146.3 & $\begin{array}{l}\mathrm{C}-2,5,7,9, \\
10\end{array}$ \\
\hline 5 & $7.31(1 \mathrm{H}, \mathrm{d}, 8.7 \mathrm{~Hz})$ & 127.2 & $C-6,7,10$ & $7.58(1 \mathrm{H}, \mathrm{d}, 8.5 \mathrm{~Hz})$ & 130.7 & $\mathrm{C}-4,7,9$ \\
\hline 6 & $6.86(1 \mathrm{H}, \mathrm{d}, 8.7 \mathrm{~Hz})$ & 107.6 & $\mathrm{C}-5,7,8,9$ & $7.06(1 \mathrm{H}, \mathrm{d}, 8.5 \mathrm{~Hz})$ & 109.7 & $\mathrm{C}-7,8,10$ \\
\hline 7 & & 160.2 & & & 162.5 & \\
\hline 8 & & 113.7 & & & 117.2 & \\
\hline 9 & & 153.0 & & & 152.8 & \\
\hline 10 & & 113.0 & & & 114.5 & \\
\hline $1^{\prime}$ & $\begin{array}{l}6.90(1 \mathrm{H}, \mathrm{d}, \\
16.4 \mathrm{~Hz})\end{array}$ & 121.6 & $\mathrm{C}-7,8,9,2^{\prime}$ & $5.57(1 \mathrm{H}, \mathrm{d}, 9.0 \mathrm{~Hz})$ & 68.1 & $\mathrm{C}-7,8,9,2^{\prime}$ \\
\hline $2^{\prime}$ & $\begin{array}{l}6.68(1 \mathrm{H}, \mathrm{dd}, \\
16.4,8.6 \mathrm{~Hz})\end{array}$ & 134.1 & $\mathrm{C}-1^{\prime}, 3^{\prime}, 5^{\prime}$ & $5.18(1 \mathrm{H}, \mathrm{d}, 9.0 \mathrm{~Hz})$ & 85.2 & $\mathrm{C}-1^{\prime}, 3^{\prime}, 1^{\prime \prime}$ \\
\hline $3^{\prime}$ & $\begin{array}{l}2.82(1 \mathrm{H}, 6.4,6.8 \\
8.6 \mathrm{~Hz})\end{array}$ & 46.7 & $C-2^{\prime}, 4^{\prime}, 5^{\prime}$ & & 143.1 & \\
\hline $4^{\prime}$ & $\begin{array}{l}4.30(2 \mathrm{H}, \mathrm{dd}, 6.8 \\
11.5 \mathrm{~Hz})\end{array}$ & 64.1 & $\mathrm{C}-2^{\prime}, 3^{\prime}, 1^{\prime \prime}$ & $\begin{array}{l}4.70,4.79 \\
(\text { each } 1 \mathrm{H}, \mathrm{s})\end{array}$ & 117.0 & $\mathrm{C}-2^{\prime}, 3^{\prime}$ \\
\hline $5^{\prime}$ & $\begin{array}{l}3.76(2 \mathrm{H}, \mathrm{dd}, 6.4 \\
11.0 \mathrm{~Hz})\end{array}$ & 63.0 & $C-3^{\prime}, 4^{\prime}$ & $1.64(3 \mathrm{H}, \mathrm{s})$ & 17.3 & $\mathrm{C}-2^{\prime}, 3^{\prime}, 4^{\prime}$ \\
\hline $1^{\prime \prime}$ & & 173.5 & & $4.28(1 \mathrm{H}, \mathrm{m})$ & 100.9 & $2^{\prime}, 2^{\prime \prime}$ \\
\hline $2^{\prime \prime}$ & $2.24(2 \mathrm{H}, \mathrm{d}, 7.1 \mathrm{~Hz})$ & 43.4 & $\mathrm{C}-1^{\prime \prime}, 3^{\prime \prime}, 4^{\prime \prime}, 5^{\prime \prime}$ & $3.37(1 \mathrm{H}, \mathrm{m})$ & 74.9 & $1^{\prime \prime}, 3^{\prime \prime}$ \\
\hline $3 "$ & $\begin{array}{l}2.12(1 \mathrm{H}, 6.6 \\
7.1 \mathrm{~Hz})\end{array}$ & 25.7 & $\mathrm{C}-1^{\prime \prime}, 2^{\prime \prime}, 4^{\prime \prime}, 5^{\prime \prime}$ & $3.37(1 \mathrm{H}, \mathrm{m})$ & 78.1 & $2^{\prime \prime}, 4^{\prime \prime}$ \\
\hline $4^{\prime \prime}$ & $0.96(3 \mathrm{H}, \mathrm{d}, 6.6 \mathrm{~Hz})$ & 22.5 & $\mathrm{C}-2^{\prime \prime}, 3^{\prime \prime} 5^{\prime \prime}$ & $3.37(1 \mathrm{H}, \mathrm{m})$ & 71.8 & $3^{\prime \prime}, 5^{\prime \prime}$ \\
\hline $5^{\prime \prime}$ & $0.96(3 \mathrm{H}, \mathrm{d}, 6.6 \mathrm{~Hz})$ & 22.5 & $\mathrm{C}-2^{\prime \prime}, 3^{\prime \prime} 5^{\prime \prime}$ & $3.27(1 \mathrm{H}, \mathrm{m})$ & 77.8 & $4^{\prime \prime}, 6^{\prime \prime}$ \\
\hline $6^{\prime \prime}$ & & & & $\begin{array}{l}3.73,3.92 \\
(\text { each } 1 \mathrm{H}, \mathrm{m})\end{array}$ & 62.8 & $5^{\prime \prime}$ \\
\hline $\mathrm{CH}_{3} \mathrm{O}$ & $3.93(\mathrm{~s})$ & 56.1 & $\mathrm{C}-7$ & $3.97(3 \mathrm{H}, \mathrm{s})$ & 56.7 & $\mathrm{C}-7$ \\
\hline
\end{tabular}

${ }^{\mathrm{a}}$ Assignments made on the basis of HSQC and HMBC. 
Compound 2 was isolated as a colorless oil and was found to have the molecular formula $\mathrm{C}_{21} \mathrm{H}_{26} \mathrm{O}_{10}$ as established by HR-EIMS ( $\left.\mathrm{m} / \mathrm{z}: 438.1528[\mathrm{M}]^{+}\right)$. Careful examination of the NMR spectra of 2 (Table 1) implied that 2 contained an 8-substituted 7-methoxy coumarin moiety, a prenylated group and an glucose moiety. The HMBC correlations between H-1' $\left(\delta\right.$ 5.57)/C-2' $(\delta 85.2), \mathrm{H}-2^{\prime}(\delta 5.18) / \mathrm{C}-1^{\prime}$ $\left(\delta\right.$ 68.1)/C-4' $\left(\delta\right.$ 117.0), H-4' $(\delta$ 4.70, 4.79)/C-2'/C-3'( $\delta 143.1) / \mathrm{C}-5^{\prime}(\delta 17.3)$ and H-5' $(\delta 1.64) / \mathrm{C}-2^{\prime} /$ C-3'/C-4'established the prenylated carbon sequence, which connected with $\mathrm{C}-8$ of the 8 -substituted 7-methoxycoumarin moiety at $\mathrm{C}-1^{\prime}$ by the HMBC signals between $\mathrm{H}-1^{\prime}$ ( $\delta$ 5.57)/C-7 (162.5)/C-8 (117.2)/C-9 (152.8). Based on the HMBC correlation from $\delta_{\mathrm{H}} 3.97(3 \mathrm{H}, \mathrm{s})$ to C-7 $(\delta 162.5)$, a methoxy group was placed at C-7. A glucose group was located at $\mathrm{C}-2^{\prime}$ as deduced from the COSY correlations between $\mathrm{H}-1^{\prime \prime} / \mathrm{H}-2^{\prime \prime}$, H-2"/H-3", H-3"/H-4", H-4"/H-5", H-5"/H-6"and the HMBC correlations between $\mathrm{H}-1^{\prime \prime}(\delta 4.28) / \mathrm{C}-2^{\prime}(\delta 85.2)$, and $\mathrm{H}-2^{\prime}(\delta 5.18) / \mathrm{C}-1^{\prime \prime}(\delta$ 100.9). Accordingly, the structure of 2 was determined as 7-methoxy-8-(1-hydroxy-2-O- $\beta$-glucopyranosyl-3-methyl-4-butene-1-yl)coumarin (Figure 1).

Figure 1. Structures of compounds 1-2 and selected HMBC correlations $(\mathrm{H} \rightarrow \mathrm{C})$ for compounds 1-2.

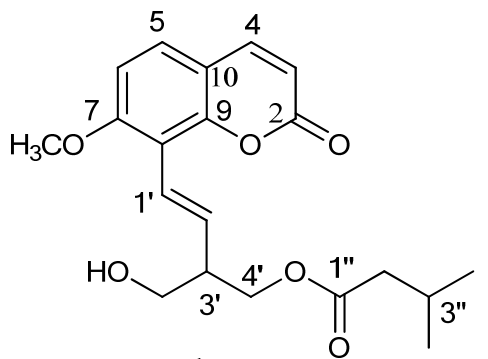

1

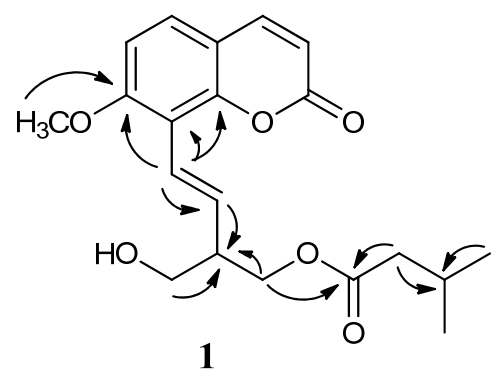

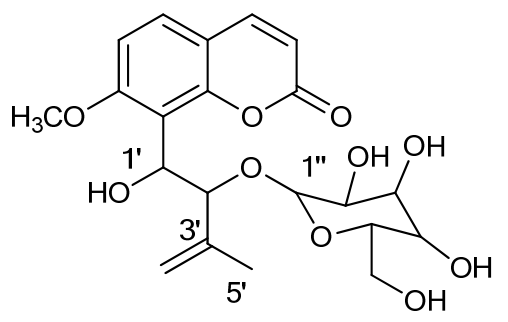

2

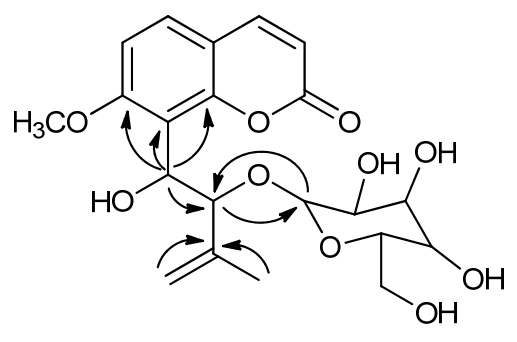

2

Toxic activities of compounds isolated from M. falcatum were tested against brine shrimp larvae using a 96 well plates assay and among all compounds tested, compound $\mathbf{1}$ had strong activity $\left(\mathrm{LC}_{50}<10 \mu \mathrm{M}\right)$, and exhibited an $\mathrm{LC}_{50}$ value of $6.8 \mu \mathrm{M}$, indicating that $\mathbf{1}$ was a potent toxic natural product. Compounds $2,3,6,7,10,11$, and 14 had moderate activity $\left(\mathrm{LC}_{50}<500 \mu \mathrm{M}\right)$, and the $\mathrm{LD}_{50}$ values of all isolated compounds are displayed clearly in Table 2.

Compounds 1-14 were further evaluated for their in vitro antiproliferative activities against mammary cancer (F10) and lung cancer (HvEvc) cell lines by the MTT method, and compounds 2, 3, and 14 displayed moderate activity against the $\mathrm{F} 10$ cell line with $\mathrm{IC}_{50}$ values of $23.6,82.9$ and $112.0 \mu \mathrm{g} / \mathrm{mL}$, respectively, and compounds $\mathbf{1}, \mathbf{2}, \mathbf{6}, \mathbf{1 0}$ and $\mathbf{1 1}$ displayed moderate activity against the HvEvc cell line with $\mathrm{IC}_{50}$ values of $35.7,68.5,172.5,72.6$ and $124.3 \mu \mathrm{g} / \mathrm{mL}$, respectively. 
Table 2. The $\mathrm{LD}_{50}$ values of compounds 1-14 against brine shrimp larvae and the $\mathrm{IC}_{50}$ values of all compounds against mammary cancer (F10) and lung cancer (HvEvc) cell lines.

\begin{tabular}{cccc}
\hline Compound & LD $_{\mathbf{5 0}}$ (brine shrimp) $\boldsymbol{\mu g} / \mathbf{m L}$ & $\mathbf{I C}_{\mathbf{5 0}}(\mathbf{F 1 0}) \boldsymbol{\mu g} / \mathbf{m L}$ & $\mathbf{I C}_{\mathbf{5 0}}(\mathbf{H v E v c}) \boldsymbol{\mu g} / \mathbf{m L}$ \\
\hline $\mathbf{1}$ & 6.8 & - & 35.7 \\
$\mathbf{2}$ & 29.1 & 23.6 & 68.5 \\
$\mathbf{4}$ & 107.3 & 82.9 & - \\
$\mathbf{5}$ & $>500$ & - & - \\
$\mathbf{6}$ & $>500$ & - & - \\
$\mathbf{7}$ & 199.3 & - & - \\
$\mathbf{8}$ & 118.5 & - & - \\
$\mathbf{9}$ & $>500$ & - & - \\
$\mathbf{1 0}$ & $>500$ & - & 72.6 \\
$\mathbf{1 1}$ & 50.6 & - & 124.3 \\
$\mathbf{1 2}$ & 158.5 & - & - \\
$\mathbf{1 3}$ & $>500$ & - & - \\
$\mathbf{1 4}$ & $>500$ & - & - \\
\hline
\end{tabular}

In addition, no antibacterial activity was observed in the test of all compounds against Bacillus subtilis (SCSIO00189), Bacillus thuringiensis (SCSIO00190) and Escherichia coli (SCSIO00191) by the K-B disk diffusion method.

\section{Experimental}

\subsection{General}

Optical rotation was measured on Polaptronic-HNQW5 high-resolution polarimeter. NMR spectra were recorded on a Bruker DRX-500 spectrometer with $\mathrm{SiMe}_{4}$ as internal standard. ESI-MS was measured with a API2000 LC/MS/MS mass spectrometer (Applied Biosystems). HREI-MS was recorded on a Thermo MAT95XP spectrophotometer. Silica gel (200-300 mesh, Qingdao Haiyang Chemical Plant, Qingdao, China) and Sephadex LH-20 (Pharmacia) were used for column chromatography. Thin layer chromatography (TLC) was carried out on precoated silica gel G plates (Qingdao Haiyang Chemical Plant, Qingdao, China) and spots were visualized by spraying the plates with $50 \% \mathrm{H}_{2} \mathrm{SO}_{4}$ solution, followed by heating. Semi-preparative RPHPLC was carried out on ODS columns (YMC-Pack ODS-5-A, $250 \times 10 \mathrm{~mm}, 5 \mu \mathrm{m}$, YMC) with the $\mathrm{CH}_{3} \mathrm{OH}-\mathrm{H}_{2} \mathrm{O}$ solvent system as eluents. A Waters 600 HPLC system equipped with a Waters 996 photodiode array detector was used for HPLC analysis.

\subsection{Plant Material}

The stem bark of M. falcatum (Lour.) Tan. was collected in October 2007 in Sanya, Hainan Province, China, and identified by Prof. Si Zhang. A voucher specimen is deposited at the Herbarium of South China Sea Institute of Oceanology (accession number: Dajian 020). 


\subsection{Extraction and Isolation}

The air-dried material M. falcatum (Lour.) Tan. $(5.0 \mathrm{~kg})$ was extracted with $95 \% \mathrm{EtOH}(50 \mathrm{~L})$ three times, respectively. The organic solvent was combined and evaporated under reduced pressure to give a residue. The residue was disolved in $2 \mathrm{~L} \mathrm{H}_{2} \mathrm{O}$ and was extracted sucessively with $n$-hexane and EtOAc $(2 \mathrm{~L}$, each $4 \times$ ) to yield $38 \mathrm{~g} n$-hexane extract and $76 \mathrm{~g}$ EtOAc extract. The EtOAc extract was separated on silica gel ( $820 \mathrm{~g}, 200-300 \mathrm{mesh})$ with solvents of increasing polarity: 10-70\% acetone in $n$-hexane followed by 5-100\% MeOH in $\mathrm{CHCl}_{3}$ to afford 102 fractions. Frs. 15-18 (2.15 g, eluted with $n$-hexane-acetone 7:3) was combined and again chromatographed on silica gel using chloroform-acetone (20:1) to afford compound 12 (135 mg). Frs. 20-21 (2.38 g, eluted with $n$-hexane-acetone 65:35) was chromatographed on silica gel with chloroform-acetone $(15: 1)$ and afforded frs. 20a-c. Fr. 20a was further purified by chromatography on Sephadex LH-20 with $\mathrm{MeOH}$ to afford compound 4 (6.8 mg), 5 (15.7 mg), 6 (12.2 mg), 8 (5.4 mg), and 13 (24.5 mg). Frs. 39-42 (2.05 g, eluted with $n$-hexane-acetone 6:4) was fractionated on silica gel using chloroform-acetone (8:2) to give compound 1 (4.8 mg), 7 (7.7 mg), 9 (14.2 mg), 10 (21.4 mg) and $\mathbf{1 1}(11.8 \mathrm{mg})$ which was crystallized from $\mathrm{MeOH}$. Frs. 45-48 (2.60 g, eluted with $n$-hexane-acetone 6:4) was fractionated on silica gel with chloroform-acetone (8:2) and then purified by semi-preparative HPLC using $\mathrm{MeOH} / \mathrm{H}_{2} \mathrm{O}$ as eluents (from 35:65 to 55:45) to yield compounds $\mathbf{2}(8.5 \mathrm{mg}), \mathbf{3}(6.1 \mathrm{mg})$, and $\mathbf{1 4}$ (10.6 mg).

7-Methoxy-8-(2-hydroxmethyl-1-O-isovaleryl-4-butenyl)coumarin (1): colorless oil; $[\alpha]^{20}{ }_{\mathrm{D}}-12.4^{\circ}$ $\left(\mathrm{CH}_{3} \mathrm{OH}, \mathrm{c} 0.33\right)$; UV (MeOH) $\lambda_{\max }(\log \varepsilon) 283.0$ (3.93), 323.3 (4.22) nm; IR (KBr) $v_{\max } \mathrm{cm}^{-1} 3540$, 1739, 1733, 1605, 1543, 1450, 1224; ${ }^{1} \mathrm{H}$ - and ${ }^{13} \mathrm{C}-\mathrm{NMR}$ data, see Table 1; Positive ESI-MS $\mathrm{m} / \mathrm{z}$ (rel.int.): $743[2 \mathrm{M}+\mathrm{Na}]^{+}$(92), $383[\mathrm{M}+\mathrm{Na}]^{+}$(100), $361[\mathrm{M}+\mathrm{H}]^{+}$(68), 316 (35); HR-EIMS m/z 360.1574 (calcd for $\mathrm{C}_{20} \mathrm{H}_{24} \mathrm{O}_{6}^{+}[\mathrm{M}]^{+}$, at $m / z$ 360.1573).

7-Methoxy-8-(1-hydroxy-2-O- $\beta$-glucopyranosyl-3-methyl-4-butene-1-yl)coumarin (2): colorless oil; $[\alpha]^{20}{ }_{\mathrm{D}}+29.5^{\circ}\left(\mathrm{CH}_{3} \mathrm{OH}, \mathrm{c} 0.74\right)$; UV (MeOH) $\lambda_{\max }(\log \varepsilon) 218.2(1.60), 246.4(0.90), 323.0$ (1.80) nm; IR (KBr) $v_{\max } \mathrm{cm}^{-1} 3542,1730,1607,1548,1450,1220,1062 ;{ }^{1} \mathrm{H}-$ and ${ }^{13} \mathrm{C}-\mathrm{NMR}$ data, see Table 1;

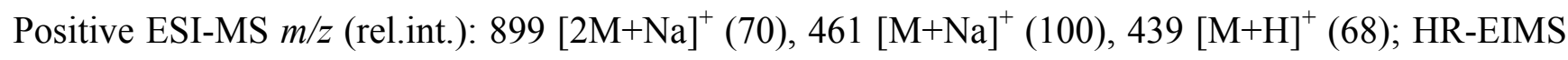
$m / z 438.1528$ (calcd for $\mathrm{C}_{21} \mathrm{H}_{26} \mathrm{O}_{10}{ }^{+}[\mathrm{M}]^{+}$, at $m / z$ 438.1526).

\subsection{The Brine Shrimp Larvae Lethality Bioassay}

According to the method described by Wanyoike [20], brine shrimp eggs (Ocean Star International, Inc., USA) were hatched in a large beaker containing natural sea water (South China Sea) and they were cultured at room temperature for $48 \mathrm{~h}$. With the help of a light source, the larvae grouped together on one side of the vessel and were easily collected for the assay. The compounds 1-14 were dissolved in dimethyl sulfoxide (DMSO) at the concentration of $50 \mathrm{mg} / \mathrm{mL}$, and then diluted in 96 well plate with $200 \mu \mathrm{L}$ sea water for testing at the final concentrations of 5,50 and $500 \mu \mathrm{g} / \mathrm{mL}$. Each test was processed in triplicate with approximate ten larvae. Brine shrimps were counted under a magnifying glass after $24 \mathrm{~h}$ of incubation and maintaining the 96 well plates under illumination. The controls were prepared in the same manner except that the test samples were omitted. The lethality of 
dead larvae was recorded and used for calculating the $\mathrm{LC}_{50}$ by the Lanyu $\mathrm{LC}_{50}$ analysis program (Version 1.01).

\subsection{Antiproliferative Assays}

Antiproliferative activities of compounds were evaluated by the MTT method using mammary cancer (F10) and lung cancer (HvEvc) cell lines. In MTT assay, the cell suspensions $(200 \mu \mathrm{L})$ at a density of $1 \times 10^{5}$ cells $\mathrm{mL}^{-1}$ were plated in 96-well microtiter plates and incubated for $24 \mathrm{~h}$ at $37{ }^{\circ} \mathrm{C}$ in a humidified incubator at $5 \% \mathrm{CO}_{2}$. The tested compound solution ( $2 \mu \mathrm{L}$ in DMSO) at different concentrations was added to each well and further incubated for $72 \mathrm{~h}$ in the same condition. Then, the MTT solution $(50 \mu \mathrm{L})$ was added to each well and incubated for $4 \mathrm{~h}$. The old medium $(150 \mu \mathrm{L})$ containing MTT was then gently replaced by DMSO. Absorbance was then determined on a Spectra Max Plus plate reader at $490 \mathrm{~nm}$.

\subsection{Antibacterial Assay}

Compounds were tested against the microorganisms Bacillus subtilis, Bacillus thuringiensis, Escherichia coli and rifampicin was used as positive control for the three microorganisms. Procedures for the antimicrobial susceptibility assays were performed using a modified method [21]. Compounds were dissolved in absolute DMSO to give the needed amounts of $0.1,1.0$, and $10 \mu \mathrm{g}$ per $6 \mathrm{~mm}$ diameter paper disk, respectively. Twelve $\mathrm{cm}$ diameter dishes, filled with LB medium, were set for each microbe species. The inhibition zones surrounding each filter paper disk were measured at the end of an incubation period of 24 or $48 \mathrm{~h}$ at $27^{\circ} \mathrm{C}$. The absolute DMSO alone showed no inhibition zone (control).

\section{Conclusions}

Bibliographical research revealed some information about the chemistry of four species of Micromelum; Micromelum falcatum, M. minutum, M. integerrimum and M. zeylanicum and that many significant 6-prenylcoumarins and 8-prenylcoumarins metabolites were isolated from them. We now report the isolation and structural elucidation of 14 coumarins including 6-prenylcoumarins [6-formyl-7-methoxycoumarin (4), murraol (6), arscotin (7), methoxymicrominutinin (13)], and 8-prenylcoumarins [7-methoxy-8-(2-hydroxmethyl-1-O-isovaleryl-4-butenyl)coumarin 7-methoxy-8-(1-hydroxy-2-O- $\beta$-glucopyranosyl-3-methyl-4-butene-1-yl)coumarin (2), microminutin (3), murralongin (5), murralonginol (8), (E)-osthenone (9), isomurralonginol (10), murracarpin (11), microminutinin (12), and microfalcatin isovalerate (14)]. From the literature prior to this study and this paper on genus Micromelum, the 6-prenylcoumarins and 8-prenylcoumarins as products of metabolism of the taxon can be attributed as indicators of chemotaxonomic significance. Compound $\mathbf{2}$, as a new coumarin glycoside, is the first glycoside reported from the genus Micromelum. The toxicity of compounds 1-14 was tested by a brine shrimp assay and in vitro antiproliferative assay against mammary cancer (F10) and lung cancer (HvEvc) cell lines by a MTT assay. No antibacterial activity of any of compounds was observed against the microorganisms Bacillus subtilis, Bacillus thuringiensis and Escherichia coli. 


\section{Acknowledgments}

This work was financially supported by the Young Scientists Fund of the National Natural Science Foundation of China (Grant No. 41006091); National Basic Research Program of China (973 Program, grant: 2010CB833800); the National Natural Science Foundation of China (Grant No. 41176149); Guangdong Province Natural Science Foundation (grant: 91510301000001). We thank the analytical facility center at the South China Sea Institute of Oceanology for recording the NMR data.

\section{References and Notes}

1. Roy, M.K.; Thalang, V.N.; Trakoontivakorn, G.; Nakahara, K. Mahanine, a carbazole alkaloid from micromelum minutum, inhibits cell growth and induces apoptosis in u937 cells through a mitochondrial dependent pathway. Br. J. Pharmacol. 2005, 145, 145-155.

2. Ma, C.Y.; Case, R.J.; Wang, Y.H.; Zhang, H.J.; Tan, G.T.; Van Hung, N.; Cuong, N.M.; Franzblau, S.G.; Soejarto, D.D.; Fong, H.H.S. Anti-tuberculosis constituents from the stem bark of micromelum hirsutum. Planta Med. 2005, 71, 261-267.

3. Sohrab, M.H.; Chowdhury, R.; Hasan, C.M.; Rashid, M.A. Chemotaxonomic significance of polyoxygenated flavonoids from the leaves of micromelum minutum. Biochem. Syst. Ecol. 2004, 32, 829-831.

4. Nakahara, K.; Trakoontivakorn, G.; Alzoreky, N.S.; Ono, H.; Onishi-Kameyama, M.; Yoshida, M. Antimutagenicity of some edible thai plants, and a bioactive carbazole alkaloid, mahanine, isolated from micromelum minutum. J. Agric. Food Chem. 2002, 50, 4796-4802.

5. Kong, Y.C.; But, P.P.H.; Ng, K.H.; Li, Q.; Cheng, K.F.; Waterman, P.G. Micromelum-a key genus in the chemosystematics of the clauseneae. Biochem. Syst. Ecol. 1988, 16, 485-489.

6. Kamperdick, C.; Phuong, N.M.; Sung, T.V.; Schmidt, J.; Adam, G. Coumarins and dihydrocinnamic acid derivatives from micromelum falcatum. Phytochemistry 1999, 52, 1671-1676.

7. Luo, X.M.; Qi, S.H.; Yin, H.; Gao, C.H.; Zhang, S. Alkaloids from the stem bark of micromelum falcatum. Chem. Pharm. Bull. 2009, 57, 600-602.

8. Luo, X.; Qi, S.; Yin, H.; Xiao, Z.; Zhang, S. Micromelosides a-d, four new coumarins from the stem bark of micromelum falcatum. Magn. Reson. Chem. 2009, 47, 1110-1114.

9. Cassady, J.M.; Ojima, N.; Chang, C.J.; McLaughlin, J.L. Potential anti-tumor agents. 11. Investigation of the anti-tumor activity of micromelum-integerrimum (rutaceae). J. Nat. Prod. 1979, 42, 274-278.

10. Ito, C.; Itoigawa, M.; Furukawa, H.; Tokuda, H.; Okuda, Y.; Mukainaka, T.; Okuda, M.; Nishino, H. Anti-tumor-promoting effects of 8-substituted 7-methoxycoumarins on epstein-barr virus activation assay. Cancer Lett. 1999, 138, 87-92.

11. Tantivatana, P.; Ruangrungsi, N.; Vaisiriroj, V.; Lankin, D.C.; Bhacca, N.S.; Borris, R.P.; Cordell, G.A.; Johnson, L.F. Microminutin, a novel cyto-toxic coumarin from micromelum minutum (rutaceae). J. Org. Chem. 1983, 48, 268-270.

12. Talapatra, S.K.; Mukhopadhyay, S.K.; Talapatra, B. Minor coumarins of boenninghausenia albiflora. Phytochemistry 1975, 14, 836-837. 
13. Allison, S.; Burks, S.J.; Taylor, R.T. Total syntheses of microminutin and other coumarins through the key intermediate isomurralonginol. Tetrahedron 1991, 47, 9737-9742.

14. Lin, J.K.; Wu, T.S. Constituents of flowers of murraya paniculata. J. Chin. Chem. Soc. 1994, 41, 213-216.

15. Wu, T.S.; Liou, M.J.; Jong, T.T.; Chen, Y.J.; Lai, J.S. Indole alkaloids and coumarins from the root bark of murraya paniculata var omphalocarpa. Phytochemistry 1989, 28, 2873-2874.

16. Gu, J.Q.; Graf, T.N.; Lee, D.H.; Chai, H.B.; Mi, Q.W.; Kardono, L.B.S.; Setyowati, F.M.; Ismail, R.; Riswan, S.; Farnsworth, N.R. Cytotoxic and antimicrobial constituents of the bark of diospyros maritima collected in two geographical locations in indonesia. J. Nat. Prod. 2004, 67, 1156-1161.

17. Imai, F.; Kinoshita, T.; Itai, A.; Sankawa, U. Acid-catalyzed rearrangement of an epoxy coumarin phebalosin the revised structure of murralongin. Chem. Pharm. Bull. 1986, 34, 3978-3981.

18. Ito, C.; Furukawa, H. Constituents of murraya exotica 1 structure elucidation of new coumarins. Chem. Pharm. Bull. 1987, 35, 4277-4285.

19. Rahmani, M.; Taufiqyap, Y.H.; Ismail, H.B.M.; Sukari, A.; Waterman, P.G. New coumarin and dihydrocinnamic acid-derivatives from 2 malaysian populations of micromelum minutum. Phytochemistry 1994, 37, 561-564.

20. Wanyoike, G.N.; Chhabra, S.C.; Lang'at-Thoruwa, C.C.; Omar, S.A. Brine shrimp toxicity and antiplasmodial activity of five kenyan medicinal plants. J. Ethnopharmacol. 2004, 90, 129-133.

21. Shen, A.Y.; Chen, C.P.; Roffler, S. A chelating agent possessing cytotoxicity and antimicrobial activity: 7-morpholinomethyl-8-hydroxyquinoline. Life Sci. 1999, 64, 813-825.

Sample Availability: Samples of the compounds 1-14 are available from the authors.

(C) 2012 by the authors; licensee MDPI, Basel, Switzerland. This article is an open access article distributed under the terms and conditions of the Creative Commons Attribution license (http://creativecommons.org/licenses/by/3.0/). 